\title{
Risks of entrepreneurial activity in a region: assessment and regulation
}

\author{
Marina E. Buyanova \\ Volgograd State University, \\ Institute of Economics and Finance \\ Chair of the Economic Theory, \\ World and Regional Economics \\ Volgograd, Russia \\ buyanovam@volsu.ru
}

\author{
Nataliya A. Mikhaylova \\ Volgograd State University, \\ Institute of Management and Regional Economics \\ Chair of the Government \\ and Municipal Administration \\ Volgograd, Russia \\ korish.m@volsu.ru
}

\begin{abstract}
The development of the entrepreneurship is accompanied by the new risks dealing with an economic activity. The most important is the suggestion of the regulation directions and also the conditions of its implementation. The entrepreneurial risk is determined by the influence of external (objective) and internal (subjective) factors. The risk control includes several stages and the first of them is the qualitative analysis of all the possible risk factors. In the article the entrepreneurial risks were analyzed which were isolated according to the indices of the economic activity conducted in the regions by entrepreneurs. Their problems and limitations are shown; the main ways of risks reduction and the directions of their regulation in the Volgograd region are suggested as well. In the paper it is shown that in the Volgograd region the commercial, economic and managerial risks (budget implementation, high government debt and its growth in prospect) are significant. The industrial risks are very high due to a high wear and tear of the fixed capital. In the region the enterprises belonging to the fuel and power complex are in a better situation. They are in the top ten of tax payers and investors. Large investment projects were started in the chemical industry. The highest risks have the enterprises of the wholesale and retail enterprises, construction firms. The significant risks are traditionally typical of agricultural enterprises but they benefit from the government support together with the enterprises of the chemical industry. Among the basic directions of the regulation of entrepreneurial risks isolated from the point of view of risk types a priority direction for the Volgograd region due to poor social and economic conditions for the entrepreneurship is the development the diversification the regional economy.
\end{abstract}

Keywords - regional economy, entrepreunership, risk management, risk regulation, economic diversification

\section{INTRODUCTION}

A negative dynamics of the number of small and medium sized enterprises is determined by high risks of the economic activity on the one hand and the absence of the means of their prevention on the other hand. The wide spread introduction of risk management systems is most impeded especially in large enterprises in view of the lack of funds, expertise and qualified specialists. For the small business the regulation of entrepreneurial risks is impossible due to the same reasons. However in present moment the situation in the market is changing and a lot of financial organizations diversifying their activity suggest a complex of services dealing this the prevention and with the insurance of the entrepreneurial risks in particular.

The structure of the regional economy has an industrial character and this sphere has entrepreneurial, ecological and other risks which are observed in the region in the whole according to its economic consequences. That's why for regional risks diversification it is indispensible to create finished consumer goods, to invent local brands, to develop the servicing sphere. This task can be realized by the small and medium sized enterprises, micro enterprises, economic risks which should have adequate ways of their regulation.

The theoretical and practical aspects of entrepreneurial risks and directions of their regulation were studied in the scientific works of I.T. Balabanov, A.N. Bordovskikh, V.M. Granaturov, V.L. Gurevich, N.I. Denisova, M.R. Dzagoeva, V.S. Kabakov, N.A. Kazakova, M. Krui, M.M. Kutjina, M.G. Lapusta, I.A. Podkolzina, G.A. Taktarov, V.N. Urodovskikh, E.A. Fedorova, V.E. Shkurko.

The most important in the analysis of the uncertainty had the papers of the classical papers of the political economy: R. Cantillon, J.M. Keynes, F. Knight.

The goal of the research is the descriptive analysis of entrepreneurial risks and the suggestion of the directions of their control in the Volgograd region. In compliance with the goal set the following tasks were solved. The assessment of the economic risks by entrepreneurs in the Volgograd region was made. The main directions of the entrepreneurial risks regulation in the region were suggested. 


\section{MATERIALS AND METHODS}

The research is based on the study of the data of the Federal Service for State Statistics of Russia and its territorial organs, information from the Ministry for Economic Development of Russia, texts of strategic and program papers of Russia, of regional and local authorities. The materials of monographic studies, scientific articles, articles of national and foreign scientists in the scientific journals and informational resources of the Internet devoted to the entrepreneurship risk and the directions of their regulation and also the risk and uncertainty analysis and the authors' calculations were used for writing this paper.

In the article different methodologies of comparative and descriptive analysis, correlation analysis were used. Also general scientific methods of structural and functional, statistical and comparative analyses, methods of classification and comparison, expert assessments method, table and graphical visualization techniques of the statistical data were employed.

\section{RESULTS AND DISCUSSION}

The entrepreneurial risk is determined by the influence of external (objective) and internal (subjective) factors. The risk control includes several stages and the first of them is the qualitative analysis of all the possible risk factors. It is indispensable to analyze the risks which the entrepreneur can not influence and these are first of all entrepreneurial risks. In the risks determination it is necessary to rely on the deductive method of research when a particular conclusion is derived from the general one.

According to the research carried out by the rating agency Expert RA in 2016 the Volgograd region had 52 $2^{\text {th }}$ rank upon the investment risk. The economic situation became better in comparison with year 2015 when the region occupied $54^{\text {th }}$ rank. It is worth studying the risks constituents of the Volgograd region (social, economic, financial, criminal, ecological and managerial) and then comparing it with the neighbouring regions of the Southern Federal District: Krasnodar krai, Rostov region (oblast) and Astrakhan region (oblast) (Table 1).

TABLE I. INVESTMENT RISKS OF THE REGIONS OF THE SOUTHERN FEDERAL DISTRICT IN 2016

\begin{tabular}{|l|l|c|c|c|c|c|c|}
\hline $\begin{array}{l}\text { Risk } \\
\text { rank }\end{array}$ & Region & $\begin{array}{c}\text { Social } \\
\text { risks }\end{array}$ & $\begin{array}{c}\text { Econ } \\
\text { omic } \\
\text { risks }\end{array}$ & $\begin{array}{c}\text { Finan } \\
\text { cial } \\
\text { risks }\end{array}$ & $\begin{array}{c}\text { Criminal } \\
\text { risks }\end{array}$ & $\begin{array}{c}\text { Ecologi } \\
\text { cal risks }\end{array}$ & $\begin{array}{c}\text { Manage } \\
\text { ial risks }\end{array}$ \\
\hline 1 & $\begin{array}{l}\text { Krasnodar } \\
\text { krai }\end{array}$ & 19 & 1 & 19 & 22 & 10 & 2 \\
\hline 21 & Rostov region & 32 & 6 & 56 & 25 & 35 & 29 \\
\hline 52 & $\begin{array}{l}\text { Volgograd } \\
\text { region }\end{array}$ & 41 & 63 & 37 & 60 & 39 & 70 \\
\hline 61 & $\begin{array}{l}\text { Astrakhan } \\
\text { region }\end{array}$ & 64 & 61 & 57 & 68 & 53 & 15 \\
\hline
\end{tabular}

Source: Made by the authors using the information [1]

The index of the integral risk in the Volgograd is significantly worse than the Rostov region and the Krasnodar krai having the minimal investment risk. The worst situation in our region is connected with the managerial risk including the quality of the administration of the regional budget. The opportunity of regional authorities to attract investments and to provide the population with the minimal level of necessary social services is included by the Expert RA into the management risk assessment.

The government debt of the Volgograd region amounted to $90 \%$ from the level of its revenues in 2016 and made up 53,4 billion rubles in comparison with 2015 and it grew by $11,7 \%$. In the year 2017 the indebtedness exceeded the total year income. In contrast to the regions of the same risk group the rates of the government debt of the Volgograd region is higher. The complexity of the situation consists in the fact that another loan will be taken in order to cover the old debt. This index of a low quality of the budget administration is one of the main constituents of the managerial risk. There exists a great probability of the risk of the non fulfillment of their obligations before the region and the program delays. Those entrepreneurs who just started their business may benefit from the minimal external risk. They have tax breaks and federal subsidies for small business. However even in order to get them they have to undergo certain procedures.

Under such conditions it will be insufficient to use only the federal subsidies, so it is indispensible to attract investments. In the region there exist not only small and medium sized firms but also there is a significant number of medium and large enterprises which are the main tax payers. In order to cover the government debt these funds are not sufficient and the region needs new tax payers. Over the past year 19 investment projects were realized. More than 135 million rubles including the construction of a technology intensive greenhouse complex for the production of vegetables with the greenhouse area of 20 hectares in the limited liability company "Ovoshchevod" in the city of Volzhskiy were invested. The first and the second phases of the green house construction were finished.

The greenhouse construction is quite a perspective business for our region. It has a priority because of the sanctions of the European Union. The share of the Volgograd region in 2015 in the total Russian production of greenhouse vegetables made up $4,6 \%$ ceding only to the market leaders. The market of the greenhouse production is vibrant today but the main impeding factor of the increase of the supply of the Russian population with national greenhouse vegetables and herbs is a too slow increase of the production capacities of industrial greenhouses. The greenhouse business is very energy intensive and requires gas, electricity. That's why many farms construct their own (sometimes several) energy centers. The construction of 1 hectare of an industrial greenhouse costs 2-3 million Euros (144-215 million rubles). Rate of energy tariffs in our region creates financial and economic risks for all economic actors and some of them have to leave the region. For instance the company "Voltire" transferred a part of the production from the city of Volzhskiy to Omsk tire plant because of a lower electricity price.

It is worth mentioning separately the risk of agricultural producers. The total volume of the agricultural complex of the Volgograd region in 2016 made up 158 billion rubles or it was $26 \%$ higher than in 2015. The index of the agricultural 
production in the fourth quarter of 2016 made up 128,7\% and in the first quarter of 2017 it made up 105,6\%. Over the past year 4,6 million tons of grain and about 1 million tons of vegetables were harvested. These values are the highest over the latest 15 years. The historical record was made in the harvesting of technical cultures (sunflower seeds) and it made up 1 million tons. But a big yield lowered the farm gate price and increased the credit insolvency risks. In the agriculture a high concentration of the risk is observed. Both low and high yields lead to risks.

The economic risk has the second place from the point of view of the importance. The region has a very high index of the tear and wear of the fixed capital $(52,4 \%)$ and this ratio corresponds to the $65^{\text {th }}$ rank from 85 positions in Russia in 2015. The Volgograd region has the worst value among the regions of the Southern federal district since 2010 [2, p. 694]. In the sector of wholesale and retail trade the degree of the tear and wear of the fixed capital makes up $71 \%$. The industry mentioned above encompasses $30 \%$ of the total number of the regional enterprises. The leading industries according to the production of the GDP in the region are the agriculture and the manufacturing production. In these industries the tear and wear of the fixed capital made up $38,4 \%$ and $47,3 \%$ correspondingly. It is worth mentioning that the agricultural producers with the help of subsidies acquired 1190 machines at the price which is $25 \%$ lower than the market value. Such a modernization took place in the region more than twenty years ago [3, p. 10].

The tear and wear of the fixed assets in the construction industry made up $62,8 \%$. This industry encompasses $9,6 \%$ of the enterprises of the region. The degree of tear and wear of the fixed capital of the enterprises working in the industry of the extraction of mineral resources is $52,1 \%$.

The Volgograd region has the worst indices upon the share of the completely worn out capital funds and this index is $24,6 \%$. In Russia by the end of 2015 even worse results had the Chechen republic $(30,6 \%)$ and the Orenburg oblast $(31,4 \%)$. In other words the situation with the completely worn capital funds is similar to the government debt and be characterized as a catastrophic one [2, p. 694]. The wholesale and retail trade in the Volgograd region has $51 \%$ of completely worn out fixed capital. The technical risks dealing with the supplies of production, its damage are significant. The economic effect of such risks is well known. The industrial enterprises of the region are certainly subject to a great industrial risk. It is the risk of the industrial degradation increase, low technological level of the largest part of the enterprises, progressing innovative and technological backwardness of industrial enterprises, gap increase in the level of the used technologies in comparison with foreign rivals, stable tendency of the reduction of the number of the employed in large and medium sized enterprises in Volgograd, bankruptcy and the pre-bankruptcy of the leading enterprises. The general risks of industrial enterprises are the constant energy cost growth what has already been mentioned above. For the chemical production which is a perspective economic direction in the region (industrial area of Public Company "Kaustik" is given to the industrial park "Nikokhim", to the Volgograd affiliate of limited liability company
"Omsktechuglerod", limited liability company "Evrokhimkaliy" eventually) high energy costs worsen the situation with the energy capacity of technological processes.

The share of organizations with losses by 01.01.2015 made up $34,7 \%$ and the growth of this type of organizations in comparison with 2014 made up 1\%. By 01.01.2016 the number of the enterprises with losses amounted to 18,9 thousand. By 01.01.2017 the share of the enterprises with losses made up $15,8 \%$. The profit of the organizations in the Volgograd region (except the financial and credit organizations) during the fourth quarter 2017 in competition with the analogous period of the previous year dropped by $45 \%$.

The economic risks in the middle term prospect lead to social risks as the largest part of the population works in the sphere of the wholesale and retail trade whose turnover dropped by $1,7 \%$ and $9,2 \%$ in 2016 correspondingly. Moreover the growth of the employed in this industry and the reduction of the employed in the agriculture and processing enterprises are observed (Table 2).

TABLE II. SHARE OF THE EMPLOYED POPULATION OF THE VOLGOGRAD REGION UPON DIFFERENT TYPES OF THE ECONOMIC ACITIVTY

\begin{tabular}{|l|c|c|c|}
\hline \multicolumn{1}{|c|}{ Type of activity } & 2013 & 2014 & 2015 \\
\hline $\begin{array}{l}\text { Wholesale and retail } \\
\text { trade }\end{array}$ & 19,3 & 19,5 & 19,6 \\
\hline Agriculture & 17,1 & 16,3 & 16 \\
\hline Processing enterprises & 15,1 & 14,9 & 14,5 \\
\hline
\end{tabular}

Source: Made by the authors on the basis of the information [2, p. 694]

The unemployment rate reduced form $7,2 \%$ in 2015 to $6,8 \%$ in 2016. By January 2017 this index amounted to $7 \%$. The index of the social risk is high enough. But it is about the average level calculated across Russia. The number of the population with the income lower than the minimum living cost in the region increased from 2012 to 2016 and in 2016 made up $15,1 \%$. The disposable income reduced for the period 2014-2016 from $100,1 \%$ to $91,2 \%$. Indirectly it evidences about the reduction of the purchasing power of the population, about the reduction of the demand for goods and services.

It is worth mentioning that in the report of the Russian Union of Industrialists and Entrepreneurs for 2016 the problem of the demand reduction was the first in the list of the business problems (Figure 1).

The reduction of the demand, of purchasing ability and of the number of potential buyers of the goods increases the probability of a commercial risk of the entrepreneurial ability. In the region there is a large percent of roads which do not respond to the normative quality requirements. The small area of roads with hard deposition sharply increases also the transport risk. Besides the absence of the loop road (at a distance form Volgograd) limits the transit potential as all the heavy vehicles use the road net of the southern part of the city of Volgograd and this all has a negative impact on the condition of the roads and on the ecology of the city. 
The universal tendency of the business situation in Russia is the lack of the qualified staff (Figure 1). $31 \%$ of the respondents speak about this risk factor. This trend is also typical of industrial enterprises of the Volgograd region. The need for workers and engineering staff till 2021 amounts to 11000 specialists including the machine construction complex (3000 people), chemical and metallurgical complex (2000 people).

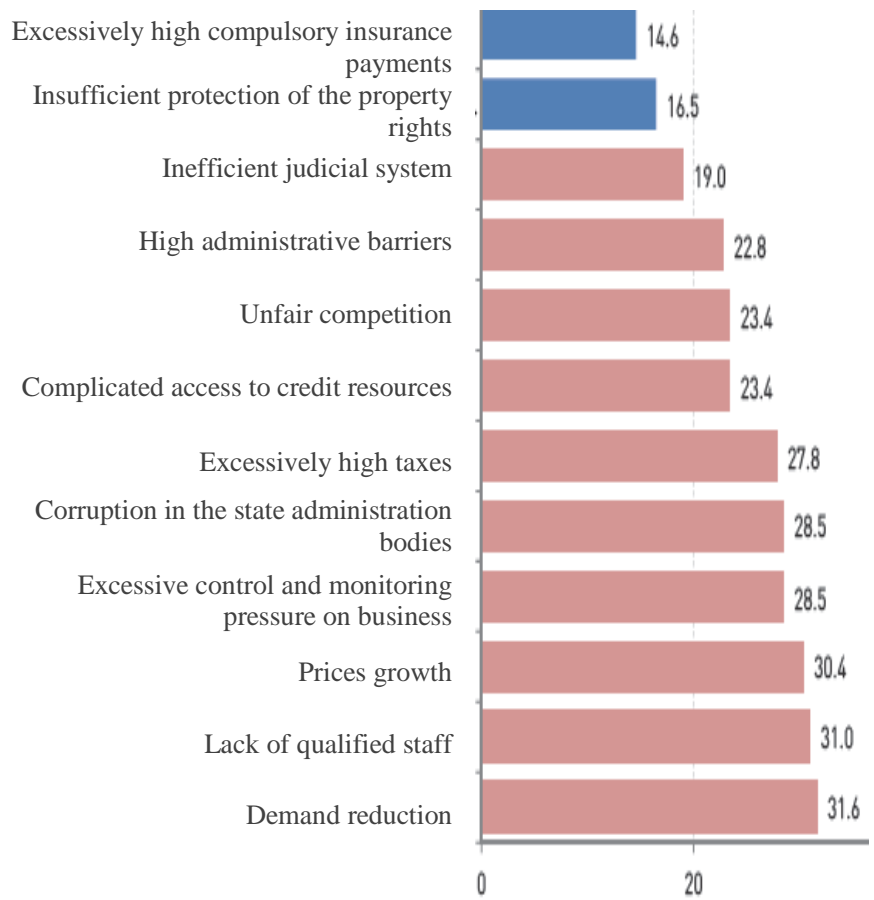

Figure 1. The most acute problems for business in Russia in 2016

Source: Made by the authors on the basis of the information [4, p. 24]

The need for another 17000 highly qualified specialists till 2023 is connected with the increase of the investment projects. At the reduction of the index of the labour productivity this circumstance speaks about the possibility of the appearance of industrial risks first of all in industrial enterprises.

The risks in the business activity are determined by such an index like overdue accounts payable of enterprises and organizations (indebtedness of the economic subject before other persons which it is obliged to pay off). This index can be found in the methodology used by the Expert RA agency. In Figure 2 the data about the organizations of the Volgograd region and other regions of the Southern Federal District are displayed.

The financial risks are assessed by the agency Expert RA as one rank lower than other types of risks in the Volgograd region. Nevertheless this type of risk for entrepreneurs in the region is quite significant. If an enterprise plans a big investment project it will be complicated to do this without the government support.

The general trend of the overdue accounts payable of the organization of the Volgograd region is an increasing one.
Thus in the Volgograd region the managerial risks (non performance of the budget, high government debt and its growth in the perspective) are significant. Industrial risks are significant due to a considerable wear and tear of the fixed capital and a high share of completely worn out capital funds. The commercial risks are determined by the following factors: reduction of the purchasing ability of the population, growth of the share of the population with the income of lower than the minimal cost of living.

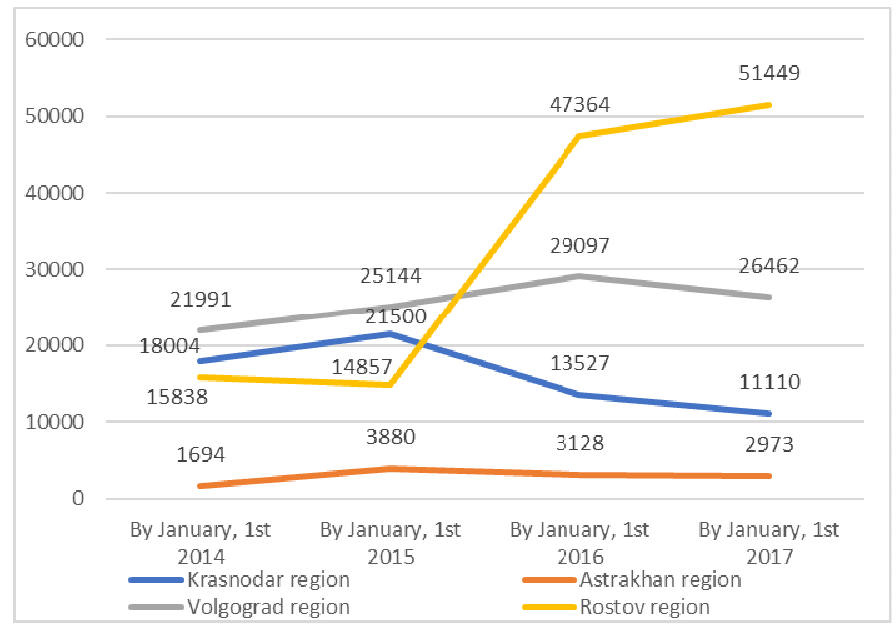

Figure 2. Overdue accounts payable of the organizations in regions of the Southern Federal District in 2014-2017, thousand rubles

Source: Made by the authors on the basis of the information [1]

All the factors mentioned above result in the reduction of the general purchasing power in the region and the decrease of the demand. This circumstance is very sensitive in the Volgograd region where the largest number of the enterprises is accumulated in the wholesale and retail trade and makes up $14,5 \%$ of the added value. And what is more the economic risk is worsened due to the reduction of the labour productivity and due to the lack of the qualified working staff in the industry. The local risks cannot be analyzed independently from one another as they are mutually conditioned and interrelated similar to the local risks of the economic actors. The risks arise at their interaction and they are hard to isolate. At the stage of the risk identification in a specific enterprise the "tree" of risks is constructed (the map of the interrelation and the mutual influence of the internal and the external risks in the company is made). The large enterprises are subject to a high probability of risks by force of the factors mentioned above. The small firms are affected by the risks to a lesser degree at the first stage of work. But then the financial risks appear and they are connected with the credits accessibility (complicated procedure of bank loans distribution), high interest rates, mortgage, undeveloped alternative mechanisms of financial and credit support. There exists an insufficient knowledge about the variants of the government support.

In the Volgograd region the enterprises from the fuel and energy complex are traditionally in a better position. They are in the top ten of the first tax payers and investors. The large scale investment projects have been started in the chemical 
industry. The highest rates have the enterprises in the wholesale and retail sector, and in the construction industry. The largest risks traditionally accompany the agricultural producers but they benefit from the government support together with the enterprises of the chemical industry.

\section{CONCLUSION}

The analysis of the conditions of the entrepreneurship allowed isolating the risks and the basic directions of their regulation.

1. The political direction of the risks regulation is presented by the political risk insurance and the introduction in 2017 of the risk targeted approach into the control and monitoring activity of the government.

The political risks are determined by the external factors which can be poorly influenced. Nevertheless the practice of political risks insurance is widely spread. Thus the Public Company EXIAR is the first export agency in the history of Russia which insures the export credits and the Russian investments abroad from the political risks. For instance the Omsk Carbon Group is the largest producer of the technical carbon and includes the limited liability company "Omsktekhuglerod". This firm is in the top twenty of the Volgograd firms from the point of view of tax payments into the regional budget in 2016. It signed the contract of the investment insurance from the political risks connected with the plant construction in the Republic of Belarus.

High managerial risks in regional authorities can be partially leveled by the introduction of the risk targeted approach which will allow reducing the general administrative load on the subjects of the entrepreneurial activity, allow increasing the efficiency of the control and monitoring activity at the optimal use of the material, financial and staff resources of the bodies of the government control.

This approach lies in the base of the decision taking in the government regulation including the acceptance of new requirements, the distribution of the budgetary financing, the classification of the control types. Within the expected results it is worth mentioning the updating of the requirements (excluding the excessive, outdated, doubling obligatory requirements) for retail sales, food production, transactions with property and so on. It is also worth noticing that the creation of the "transparent conditions for the entrepreneurship". The introduction of the risk targeted approach is the example of the risk mitigation by means of the creation of the system of the risk management at the regional (meso) level.

2. Economic direction of the entrepreneurial risk regulation includes the following aspects.

- Diversification of the activity of a specific enterprise and the diversification of the regional economy are priority direction of the economic policy in the Volgograd region as the economic and social constituents are in a crisis situation;

- Insurance of the industrial risks and the non payment risks, complex insurance of the companies exporters. The derivatives are used as the tools for the insurance of the credit and currency risks;

- Methods and measures of the reduction of the tax risks. For instance the practice of the bringing of an entrepreneur to the subsidiary and criminal responsibility for the indebtedness in tax payments and before the partners [5];

- Government guarantees (government tax remissions, "Program 6,5\%" and other easy loans and government support measures) as a way of the risk reduction.

The analysis of the existing entrepreneurial risks in the region, the conditions of the economic activity showed that the practice of the use of various ways of risks reduction is not considerable. The additional expenses and low knowledge, poor managerial culture are the main reasons for the risk reduction. The same reason is mentioned by the regional authorities without speaking of the reluctance of industrial enterprises to take part in the government programs. The experts in their turn mention significant barriers for such a participation.

The enterprises of the region which have already received the loans through the Fund for Industrial Development (Public Company "Volgograd ceramic plant", Volgograd Aluminum plant "Rusal", Private Company "NPO Akhtuba" and others) insure the industrial risks and for the present moment take part indirectly in the creation of an integrated regional system of the preparation of the workers and of the engineering staff.

Thus the insurance of the producer responsibility is a tool of the minimization of the risks of industrial enterprises of the Volgograd region. The production and the sales of goods can lead to the life injury, harm to health or to the property of third persons (consumers) independently from the fact whether the consumers had the contract obligations with the producer, the damage is to be reimbursed. This can impact the financial stability of an industrial enterprise (or a company), it can divert money from the main activity of the producer (seller) and it helps avoid the negative consequences mentioned above.

From the part of the business the demand for the banking guarantees and letters of credit is growing [6, p. 13-14]. These tools insure the non payment risks as inside the private enterprises the risk management is not so widely used like in a bank. However a lot of insurance companies suggest such a product like "insurance of entrepreneurial risks". The most popular loan programs among the entrepreneurs today are the loans which add funds to the current capital.

Thus it is worth noticing that among the main directions of the entrepreneurial risks regulation isolated from the point of view of risk types the priority direction for the Volgograd region in force of poor social and economic conditions for the entrepreneurial activity is the diversification of the regional economy and it is considered to be the priority variant. 


\section{References}

[1] Regional rankings. Official site of the rating agency Expert RA [Reitingi regionov. Ofitsial'nyi sait reitingovogo agenstva Ekspert RA], 2016. Available at: http://raexpert.ru/ratings/regions. Date of reference: 11.01.2018.

[2] Regions of Russia. Social and economic [Regiony Rossii. Sotsial'noekonomicheskie pokazateli] Moscow: Rosstat Publ., 2016, p. 694.

[3] Dmitrieva, T. The Crisis tonicity [Krizisnyi tonus]. Kommersant [Kommersant], 2017, no, 53, p. 10.
[4] Report "About the state of the business climate in Russia in 2016" [Doklad «O sostoyanii delovogo klimata v Rossii v 2016 godu»]. Moscow, 2017, p. 24. - Available at http://media.rspp.ru/document/1/f/9/f9c2ca5f8cd104f8d5d40f2a7b50fce d.pdf. Date of reference: 11.01.2018.

[5] Portnov, G. In the dialogue mode [V rezhime dialoga]. Kommersant [Kommersant], $2017 . \quad$ - $\quad$ Available at: https://www.kommersant.ru/doc/3256669\#comments. Date of reference: 15.01.2018.

[6] Artemov, S. Three Growth Factors [Tri faktora rosta]. Kommersant [Kommersant], 2016, no. 231, pp. 13-14. 